\title{
REFORMING THE PRIVATE SECTOR'S ROLE IN DETERRING CORPORATE MISCONDUCT
}

\author{
STANLEY SPORKIN*
}

In considering the subject of deterring corporate misconduct, several facts need to be put on the table. First, the government does not have either the resources or, in certain instances, the inclination to fight corporate crime. Some observers say the executive and legislative branches may well have been coopted by a public relations campaign aimed at curtailing lawsuits. This observation has been fueled by jury verdicts that seem disproportionate to the injuries sustained. W itness, for example, the large award against M CD onald's for serving a cup of coffee that was too hot. ${ }^{1}$

Essentially, that leaves the private sector to fend for itself. In the private sector, however, there have been too many instances where inappropriate and excessive settlements have brought about negative reactions from the citizens and Congress. This has further curtailed efforts to reign in corporate crime. Q uestionable class action lawsuits have been brought in the private sector and the public relations firms of those sued have obtained tremendous mileage on behalf of their corporate clients in bringing about opprobrium to class action lawsuits.

While this state of affairs continues, the ordinary citizen is greatly injured. $\mathrm{H}$ ere is what I have said in the past about white collar crime:

While all this is taking place, I see little if anything anyone, except perhaps the SE C, is doing to stamp out White Collar crime. Y es, in this area where resources are available, your enforcement official continues to use the old fashioned technique of reacting on a case-by-case basis. U nfortunately, this is like killing individual ants instead of adopting a strategy to wipe out the entire ant colony. What is particularly troubling is that in many instances, law enforcement authorities are willing to take the easy way out. Plea bargains that scale back the charges are often in the interest of the [g]overnment just as much as they are in the interest of the [d]efendant. The last thing a law enforcement agency wants is to litigate a protracted complex criminal or civil action. The [g]overnment agency, sometimes without the skill to properly investigate a complex case, builds one that is error prone. The official, aware that a trial might reveal serious deficiencies in the underlying investigation, takes the easy way out by accepting a minimal plea to the conduct charged. 2

Copyright $\odot 1997$ by L aw and Contemporary Problems

This article is also available at http://www.law.duke.edu/journals/lcp.

* U nited States J udge, D istrict of Columbia.

1. See A ndrea G erlin, A Matter of Degree, WA LL. ST. J ., Sept. 1, 1994, at A 1; A ric Press, A re L awyers B urning A merica?, N E W sWEE K, M ar. 20, 1995, at 32.

2. See Stanley Sporkin, A ddress at The Scamming of A merica, Corporate Crime in A merica Program, W ashington, D.C. (O ct. 17, 1997). 
What can we do about this state of affairs? O ne hopes that the government will find a way to increase its resources. With citizens losing billions of dollars each year to the scam artist, you would think the government would commence a war on white collar crime as it has against the drug dealer. U nder today's circumstances, however, not much help can be expected from Congress.

This leaves the private sector-particularly the plaintiff's bar-to seek redress for corporate law breakers. For its own good, then, the plaintiff's bar must refrain from bringing non-meritorious actions or settling lawsuits where the only group that recovers meaningful damages is the lawyers. This is fact. J ust read the Wall Street J ournal and you will see evidence of this statement. It has gotten to be so good that the defense bar has bought into the system. The airline antitrust case ${ }^{3}$ discussed below is an example of this. The case can be made that too many lawsuits are brought for the lawyers' benefit rather than the clients' interests.

The legal profession may do well to rethink the reasons for its existence. The private antitrust airline settlement tells you something is amiss. B ecause I could not do justice in recounting the case that gave the public certain ten to twenty-five dollar discount coupons while the lawyers walked off with $\$ 16$ million in fees, I am going to quote from a story in the Washington P ost:

The coupons do offer sufficient incentive that consumers want to use them, making them an effective marketing tool for the airlines. In fact, A laska A irlines, one of the few large carriers not named in the original case, asked to be a defendant when it learned of the coupon program and was accomodated.

"The airlines using those coupons are going to see substantial additional ticket sales because of them," said L ouis Cancelmi, a spokesman for A laska A ir. "We asked to be named in the case because, once we saw the settlement, we realized it was to our competitive disadvantage not to do so." 4

It stretches credulity to think that someone would want to be named as a defendant in a lawsuit. If this trend continues, I can foresee some enterprising lawyer sending out a notice to putative members of a defendant class urging them to accept defendant status in order to get in on a "sweetheart" deal.

R ecently, the plaintiff's bar has suffered some setbacks. Courts in Louisiana and Pennsylvania rejected proposed consent decrees because they were inadequate to address the alleged injuries the plaintiffs sustained. ${ }^{5} \mathrm{O}$ bviously, if this trend continues, the system working as it should will have effected needed change. Let me make it clear that while I believe change is needed to rid the system of the frivolous lawsuit or of the lawsuit that principally benefits counsel, I do not subscribe to the drastic changes that are being discussed elsewhere. Persons who have been injured certainly need access to a fair and impartial dis-

3. See In re Domestic A ir Transp. A ntitrust L itig., 148 F.R .D. 297 (N .D . G a. 1993).

4. A nthony Faiola, In Settling with Airlines, There's No Free Ride; Coupons for Travelers, $\$ 16$ M illion for L awyers, W A SH. POST, M ar. 20, 1995, at A 1.

5. See Castano v. A merican Tobacco Co., 64 F.3d 734 (5th Cir. 1996); Georgine v. A mchem Prods. Inc., 83 F.3d 610 (3d Cir. 1996). 
pute resolution system and to be compensated commensurate with the injuries suffered.

Consider the proposed tobacco settlement. A Ithough there has been talk of a settlement of billions of dollars, the cancer-ridden person will get not very much, if anything, out of the settlement. With all this money, it is surprising that there is no suggestion for establishing a "superfund" to make payments to the victims without their having to take on the tobacco industry on a case-bycase basis.

It is time for thoughtful consideration to be given to these issues. R eform is necessary and I would like to see the debate start as soon as possible. To commence this process, here are a few suggestions for reform:

1. We must insist that the government do more. The Securities and Exchange Commission ("SE C"), as small an agency as it is, has taken some incredible steps to protect investors. For example, in the Prudential case, at a time when the bar was willing to settle for a few cents on the dollar, the SEC recouped more than one billion dollars for investors. ${ }^{6}$ V irtually every injured investor received a substantial recovery. There are other instances where the SE C has stepped in and obtained substantial recoveries for defrauded investors. This must continue.

2. The private bar must also do its share. It must bring only appropriate cases and obtain relief by settlement or otherwise that withstands the criticism that the lawyers' compensation was the paramount issue in the litigation. In every ease, counsel must stop and ask these questions: Is the proposed settlement in the clients' best interest? A m I prepared to defend this settlement in the court of public opinion? W ill the public agree that I have done something to further the cause of justice?

3. I realize the plaintiffs' bar is diverse and highly competitive. I also realize that, on occasion, lawyers are going to step over the line. To curtail such abuses, a code of ethics must be developed and made applicable to plaintiffs' and defendants' counsel engaged in class action lawsuits. It should cover all phases of the lawsuit, from its inception to its ultimate disposition. A dditionally, a "D ear A bby" group should be established to respond to ethical questions on a real-time basis.

6. See In re Prudential-Bache Energy Income Partnerships Sec. Litig., M D LA N o. 888, 1995 WL 700216 (E.D. La. Nov. 28, 1995); SE C v. Prudential Sec., Inc., Civ. A. No. 93 Civ. 2164, 1993 WL 473189 (D.D.C. O ct. 21, 1993). M any thanks to the law firm of Storch \& Brenner (special master in the SE C case and overseer of the disbursement), especially Larry Storch, J oel Brenner, and M ichael Dixson for helping gather the information for this footnote. 
M y final idea is not yet fully developed. In qui tam actions, ${ }^{7}$ private parties learning of fraud, waste, or mismanagement of a government entity can bring a lawsuit against those causing the government losses. The private parties must first notify the government of the lawsuit; the government is then given a certain amount of time to determine whether to take over the case. If the government does take over the case, the original plaintiff can receive up to twentyfive percent of the funds recovered. In some instances, this could be a tidy sum.

This nation's securities markets and its corporate finance system are without parallel. They are the envy of the world, but they can remain so only if they maintain their integrity. O verreaching and other misconduct must be kept to a minimum. O ne of the great aspects of our system is its private attributes, both in the capital formation and policing functions.

The government has made great strides in allowing virtually unrestricted access to this nation's financial markets with minimal oversight. In the policing area, there has been and must continue to be a shared responsibility. The government, principally through the work of the SE C, has discharged its responsibilities in an exemplary fashion. The private sector must uphold its part. Because the private sector has made some missteps in recent times, Congress has stepped in to curtail its powers. This is largely because the private sector has not been vigilant in policing itself. To avoid government curbs, the private sector must devise a method for keeping excesses to a minimum. To do this, the private sector must adopt, where practicable, voluntary measures to prevent overreaching. Symposia like this one are a big step in developing an agenda for self evaluation and appropriate introspection. Once a system of reform has been fully debated and accepted by the plaintiffs' bar, restraint must be exercised to assure adherence to the enunciated principles. O nly in this way will the private policing system be able to avoid congressional intervention and do its share to maintain the integrity of our securities markets and corporate finance system.

7. The term "qui tam" derives from the Latin phrase "qui tam pro domino rege quam pro se imposo sequitur," meaning "who brings the action as well for the K ing as for himself." See Bass A nglers Sportsman's Soc'y v. U.S. Plywood-Champion Papers, I nc., 324 F. Supp. 302, 305 (S.D. Tex. 1971). See generally Jill E. Fisch, Class Action Reform, Qui Tam, and the Role of the Plaintiff, 60 LAW \& CONTEMP. PROBS. 167 (A utumn 1997). 